\title{
Pendampingan Majelis Ta'lim dan Kelompok Wirid Yasin dalam Mengembangkan Ekonomi Kreatif Anyaman Tradisional
}

\author{
Sofia Ridha', Muhammad Taufik², Fauzan ${ }^{3}$, Fajriani Arsya \\ Institut Agama Islam Negeri Bukittinggi, sofiaridha70@gmail.com \\ Institut Agama Islam Negeri Bukittinggi, m.taufik@gmail.com \\ Institut Agama Islam Negeri Bukittinggi, fauzanb@gmail.com \\ Institut Agama Islam Negeri Bukittinggi, fajriani.arsya..ma@gmail.com
}

2021 by the authors. Submitted for possible open access publication under the terms and conditions of the Creative Commons Attribution-ShareAlike 4.0 International License-(CC-BY-SA) (https://creativecommons.org/licenses/by-sa/4.0/) DOI: http://dx.doi.org/10.30983/dedikasia.vli2.5297

\begin{tabular}{l}
\hline ARTICLE INFO \\
\hline Submit $\quad: 25$ September 2021 \\
Revised $\quad: 30$ November 2021 \\
Accepted $\quad: 30$ Desember 2021 \\
Keywords: \\
Pendampingan; Majelis Ta'lim; Ekonomi \\
Kreatif; Anyaman; Tradisional
\end{tabular}

International License-(CC-BY-SA)

(https://creativecommons.org/licenses/by-sa/4.0/)

di) http://dx.doi.org/10.30983/dedikasia.vli2.5297
ABSTRACT

Majelis Ta’lim dan kelompok Rabitah Wirid Yasin (RAWIYA) Perempuan Jorong Batu Badinding merupakan salah satu kelompok masyarakat yang ada di pedesaan yang memiliki aktivitas bersama dengan berbagai kegiatan khusus keagamaan. Namun karena lemahnya keterampilan tangan yang dimiliki sehingga sebagian besar dari mereka hanya mengandalkan sumber kehidupan adalah peladang di hutan dan juga peladangan pertanian. Metode pelaksanaan dengan metode Partisipasi, dengan pendekatan keterlibatan dalam kegiatan. Pengabdian masyarakat berbasis riset mengenai peningkatan ekonomi kreatif melalui Anyaman Tradisional sebagai sarana dan wadah bagi penyadaran terhadap masyarakat khususnya ibu-ibu rumah tangga yang tergolong dalam kelompok majelis talim dan rabithah wirid yasin untuk menjadi masyarakat yang hanya sebagai konsumen menuju kepada produsen. Kegiatan pengabdian masyarakat ini telah memberikan efek positif bagi pengetahuan dan keterampilan bagi majelis ta'lim dan kelompok wirid yasin. Kelompok majelis ta'lim dan rabithah wirid yasin telah menyadari akan perlunya keterampilan untuk memanfaatkan tumbuh-tumbuahan sekitar untuk dijadikan sumber pengambah pendapatan keluarga m,elalui hasil anyaman yang dapat dijual bagi wisatawan yang berkunjung ke kecamatan Bonjol yang menjadi salah satu destinasi wisata sejarah di kabupaten Pasaman.

\section{Introduction}

Kelompok Majelis Ta'lim dan Rabitah Wirid Yasin (RAWIYA) perempuan, merupakan salah satu bentuk sisi kehidupan berkelompok dalam berbagai kegiatan bermasyarakat yang ada di Indonesia. Kelompok majelis Ta'lim dan Rabithah Wirid Yasin Perempuan menjadi salah satu aset khususnya perempuan muslimah. Namun dalam kenyataan hidup tidak sedikit pula kelompok majelis Ta'lim dan Rabithah Wirid Yasin (Rawiya) mengalami ketertinggalan khususnya dalam hal ekonomi. 
Ketertinggalan tersebut bukan tanpa suatu alasan. Kondisi ini disebabkan oleh basis ekonomi dan pendidikan yang rendah, pengetahuan yang minim, serta jauh dari informasi dan tekhnologi. Berbagai program-program pemberdayaan masyarakat dari pemerintah, selain upaya mengentaskan kemiskinan juga sebagai memberdayakan (empower), masyarakat melalui gerak dari bawah dan merupakan prakondisi penting bagi segala macam strategi untuk mencapai pembangunan yang sukses.

Majelis Ta'lim dan kelompok Rabitah Wirid Yasin (RAWIYA) Perempuan Jorong Batu Badinding merupakan salah satu kelompok masyarakat yang ada di pedesaan yang memiliki aktivitas bersama dengan berbagai kegiatan khusus keagamaan. Namun karena lemahnya keterampilan tangan yang dimiliki sehingga sebagian besar dari mereka hanya mengandalkan sumber kehidupan adalah perladang di hutan dan juga peladangan pertanian.

Untuk menopang ekonomi keluarga maka kaum perempuan ikut berpartisipasi dalam mencari kebutuhan keluarga dengan mengolah lahan pertanian dan perladangan. Walaupun para peempuanperempuan ini membanting tulang dalam bekerja dalam menambah penghasilan keluarga namun ekonomi keluarga mereka lemah. Mereka masih kesulitan dalam menyekolahkan anak-anak. Hal ini tidak terlepas dari rendahnya SDM yang mereka miliki. Mereka memiliki hasil pertanian namun mereka tidak punya skill untuk mengolahnya. Akibatnya hasil-hasil pertanian dari perladangan mereka itu mereka jual seadanya, tentunya hal ini menyebabkan nilai jual yang rendah. Hal ini tentu saja belum dapat merubah kesejahteraan secara signifikan.

Signifikansi dari kegiatan pengabdian masyarakat ini, mengingat kondisi kehidupan sosial ekonomi anggota Majelis Taklim (MT) dan Rabithah Wirid Yasin (RAWIYA) perempuan pedesaan tergolong rendah.Rendah ekonomi yang disebabkan oleh lemahnya kemandirian padahal daerah mereka memiliki sumber daya alam yang dapat dimanfaatkan untuk sumber ekonomi. Berdasarkan isuisu kondisi anggota Majelis Ta'lim dan Rabithah Wirid Yasin (RAWIYA), di atas maka kegiatan pengabdian berbasis riset sangat signifikan untuk dilaksanakan mengingat kegiatan pengabdian berbasis riset ini, mengungkap permasalahan sosial ekonomi anggota majelis ta'lim/Rabithah wirid yasin untuk meningkatkan keterampilan sebagai sarana untuk meningkatkan ekonomi keluarga. Kegiatan ini, signifikan untuk dilaksanakan dengan pertimbangan bahwa:

1. Pentingnya pengkajian secara riset terhadap sosial, ekonomi anggota Majelis Taklim perempuan dan Rabithah Wirid Yasin

2. Pentingnya penelitian terhadap permasalah keterampilan ekonomi kreatif bagi anggota MT dan Rawiya

3. Pentingnya menumbuhkembangkan usaha ekonomi kreatif bagi anggota MT dan Rawiya

4. Pentingnya memberikan pembekalan ekonomi kreatif bagi anggota Majelis Ta'lim dan Rawiya

5. Pentingnya memberikan evaluasi terhadap dampak dari kegiatan ekonomi kreatif bagi anggota Majelis Taklim dan Rawiya Perempuan

Pelaksanaan kegiatan pelatihan anyaman yang dilakukan bagi majelis ta'lim di jorong Batu Badinding menggunakan konsep pemberdayaan. Pemberdayaan pada hakikatnya mengandung dua 
kecendrungan. Pertama, yang menekankan kepada proses memberikan atau mengalihkan sebagian kekuasaan, kekuatan atau kemampuan kepada masyarakat agar individu menjadi lebih daya, yang merupakan makna kecenderungan primer. Kedua, kecenderungan sekunder menekankan pada proses menstimulasi, mendorong atau memotivasi individu agar mem nyai kemampuan atau keberdayaan untuk menentukan apa yang menjadi pilihan hidupnya melalui proses dialog (Onny S. Priy dan Pranarka, 1996: 56 -57 dalam Roesmidi dan Riza Ristianti: 2008). Dalam konteks pembangunan istilah pemberdayaan pada dasarnya bukanlah istilah baru melainkan sudah sering dilontarkan semenjak adanya kesadaran bahwa faktor manusia memegang peran penting dalam pembangunan.

Pemberdayaan adalah sebagai berikut. "Membebaskan seseorang dari kendali yang kaku, memberi orang tersebut kebebasan untuk bertanggung jawab terhadap ide-idenya, keputusan-keputusannya dan tindakannya". Pemberdayaan juga dimaknai sebagai. "Upaya memberi keberanian dan kesempatan pada individu untuk mengambill tanggung jawab perorangan guna meningkatkan cara kerja mereka dan memberikan kontribusi pada tujuan organisasi."Dengan demikian terlihat jelas bahwa pemberdayaan bukanlah proses sepihak, melainkan proses yang dijalankan untuk kepentingan bersama. Pemberdayaan sebagai terjemahan dari "empowerment" menurut sarjana lain, pada intinya diartikan sebagai berikut:"Membantu klien memperoleh daya untuk mengambil keputusan dan menentukan tindakan yang akan ia lakukan yang terkait dengan diri mereka, termasuk mengurangi efek hambatan pribadi dan sosial dalam melakukan tindakan. Hal ini dilakukan melalui peningkatan kemampuan dan rasa percaya diri untuk menggunakan daya yang ia miliki, antara lain melalui transfer daya dari lingkungannya"

Pengkaji pemberdayaan, sebagian besar literatur mengakui pentingnya rumah tangga sebagai sumber utama pemberdayaan. Hal ini diungkapkan oleh Friedmann (1992: 32-33) menulis bahwa dalam rumah tangga ada tiga macam kekuatan yaitu sosial, politik, dan psikologis. Kekuatan sosial menyangkut akses terhadap dasar-dasar produksi tertentu suatu rumah tangga misalnya informasi, pengetahuan dan keterampilan, partisipasi dalam organisasi sosial sumber-sumber keuangan. Bila ekonomi rumah tangga tersebut meningkatkan aksesnya pada dasar-dasar produksi maka kemampuannya dalam menentukan dan mencapai tujuannya juga meningkat atau dengan kata lain ada peningkatan kekuatan sosial. Kekuatan politik meliputi akses setiap anggota keluarga terhadap proses pembuatan keputusan terutama keputusan mempengaruhi masa depan mereka sendiri. Kekuatan politik bukan hanya kekuatan untuk memberikan suara, tetapi juga merupakan kekuatan untuk menjadi vokal dan bertindak secara kolektif.

Selain kedua kekuatan di atas, rumah tangga juga andalkan eksistensinya pada kekuatan psikologis yang digambarkan sebagai rasa potensi individu (individual sense of potency) yang menunjukkan perilaku percaya diri. Rasa potensi pribadi yang semakin tinggi akan memberikan pengaruh positif terhadap perjuangan rumah tangga yang secara terus menerus berusaha untuk meningkatkan kekuatan-kekuatan sosial politiknya. Dari ketiga kekuatan tadi yang patut mendapat perhatian utama adalah pemberdayaan sosial kaum miskin dengan cara mendorong memberdayakan 
politik supaya mereka dapat juga berpartisipasi dalam tindakan-tindakan politik dan sosial yang relevan.

Pemberdayaan mendorong terjadinya suatu proses perubahan sosial yang memungkinkan orang-orang pinggiran yang tidak berdaya untuk memberikan pengaruh yang lebih besar pada arena politik secara lokal maupun nasional. Oleh karena itu pemberdayaan sifatnya individual sekaligus kolektif. Pemberdayaan merupakan suatu proses yang menyangkut hubungan-hubungan kekuatan/ kekuasaan yang berubah antara individu, kelompok dan lembaga-lembaga sosial. Di samping itu pemberdayaan juga merupakan proses perubahan pribadi karena masing-masing individu mengambil tindakan atas nama diri mereka sendiri dan kemudian mempertegas kembali pemahamannya terhadap dunia tempat ia tinggal. Persepsi diri bergerak dari korban (victim) ke pelaku (agent) karena orang mampu bertindak dalam area sosial politik dan berusaha memenuhi kepentingannya.

Pemberdayaan dibedakan menjadi empat macam dilihat dari sasaran ruang lingkupnya, yaitu sebagai berikut.

a. Pemberdayaan pada individu anggota organisasi anggota masyarakat;

b. Pemberdayaan pada tim atau kelompok masyarakat

c. Pemberdayaan pada organisasi; dan

d. Pemberdayaan pada masyarakat secara keseluruhan

Dilihat dari sasaran dan ruang lingkup tadi pembahasan yang akan dilakukan dalam konteks pemberdayaan masyarakat akan lebih terfokus pemberdayaan masyarakat, pemberdayaan pada tim atau kelompok masyarakat. Namun mengingat kelompok masyarakat terdiri pula dari anggota masyarakat maka dengan sendirinya akan dibahas pula pemberdayaan pada indi anggota masyarakat. Lebih mendalam Abu Huraerah (2008: 81) menjelaskan bahwa pemberdayaan merupakan terjemahan dari istilah empowerment. Di Indonesia, istilah pemberdayaan sudah dikenal dengan NGOs, baru setelah Konferensi Beijing 1995 menggunakan istilah yang sama. Dalam perkembangannya istilah pemberdayaan telah menjadi wacana (discourse) publik dan bahkan seringkali dijadikan kata kunci (key word) bagi kemajuan dan keberhasilan pembangunan masyarakat.

Pemberdayaan masyarakat adalah sebuah konsep ekonomi yang merangkum nilai-nilai sosial. Konsep ini mencerminkan paradigma baru pembangunan, yakni bersifat "people-centered, participatory, empowering, and sustainable" Konsep ini lebih semata-mata memenuhi kebutuhan dasar (basic needs) atau lebih menyediakan mekanisme untuk mencegah proses pemiskinan lebih lanjut. yang pemikirannya akhir-akhir ini banyak dikembangkan sebagai upaya mencari alternativ terhadap konsep-konsep pertumbuhan masa lalu.

Konsep ini tidak mempertentangkan pertumbuhan dengan pemerataan seperti dikatakan Donald Brown, keduanya tidak harus diasumsikan sebagai "incompatible or antithetical". Konsep ini konsep ini mencoba melepaskan diri dari perangkap "zero sum game" dan "trade off" Ia bertitik tolak dari pandangan bahwa dengan pemerataan tercipta lebih luas untuk pertumbuhan dan yang akan 
menjamin pertumbuhan yang berkelanjutan. Kriya kerajinan anyaman tradisional adalah seni kerajinan kriya berbahan dasar dari tumbuh-tumbuhan sejenis pandan yang dikenal masyarakat dengan nama mansiang berlokasi di jorong Batu Badinding. Kriya kerajinan anyaman tradisional Batu badinding yang terbuat dari mansiang (pandan yang telah dikeringkan), bukanlah karya yang dibuat dengan intensitas rajin semata, di dalamnya terkandung nilai keindahan (estetika) dan juga kualitas skill yang tinggi. Sedangkan kerajinan tumbuh atas desakan kebutuhan praktis dengan mempergunakan bahan yang tersedia dan berdasarkan pengalaman kerja yang diperoleh dari kehidupan.

Dalam kaitannya dengan seni kriya, Gustami (2004:17) berpendapat bahwa seni kriya adalah "karya seni yang unik dan punya karakteristik" di dalamnya terkandung muatan-muatan nilai estetik, simbolik, filosofis dan sekaligus fungsional oleh karena itu dalam perwujudannya "didukung craftsmanship yang tinggi, akibatnya kehadiran seni kriya termasuk dalam kelompok seni-seni adiluhung" (Gustami, 1992:71). Lebih mendalam membahas tentang seni kriya kembali mempertegas bahwa dalam seni kriya terdapat beberapa jenis seni kriya di antaranya adalah "l) seni kerajinan kulit; 2) seni kerajinan logam 3) seni ukir kayu; 4) seni kerajinan anyaman; 5) seni kerajinan batik; dan 6) seni kerajinan keramik".

Sedangkan seni anyaman adalah seni keterampilan tangan atau kriya yang tumbuh berkembang di tengah-tengahmasyarakat Indonesia sejak dari zaman dahulunya lahir dan tumbuh di tengah-tengah kehidupan masyarakat Indonesia. Anyaman lahir sebagai bentuk dari pemanfaatan sumber daya alam yang ada. Bahan baku dari anyaman adalah tumbuh-tumbuhan pandan yang merupakan tumbuh-tumbuhan yang hidup, tumbuh dan berkembang di lingkungan masyarakat indonesia pada umumnya. Anyaman menjadi salah satu seni kriya adalah dari tumbuh-tumbuhan pandan yang dipakai dan dijumpai hampir di setiap daerah di Indonesia. Adapun bahan dasar pandan sebagai pembuatan barang kriya, memiliki perbedaan antara satu jenis produk dengan produk lainnya.

Seni Kriya kerajinan adalah "suatu hal yang bernilai sebagai kreativitas alternatif, suatu barang yang dihasilkan melalui keterampilan tangan”. Umumnya, barang kerajinan banyak dikaitkan dengan unsur seni yang kemudian disebut "seni kerajinan". Seni kerajinan adalah implementasi dari karya seni kriya yang telah diproduksi secara massal. Produk massal tersebut dilakukan oleh para pengrajin. Kerajinan yang berkaitan dengan buatan tangan atau kegiatan yang berkaitan dengan barang yang dihasilkan melalui keterampilan tangan (kerajinan tangan), kerajinan yang dibuat biasanya terbuat dari berbagai bahan. Kerajinan tersebut menghasilkan hiasan atau benda seni maupun barang pakai. Biasanya istilah ini diterapkan untuk cara tradisional dalam membuat barang-barang kebutuhan seharhari.

Kerajinan adalah "suatu hal yang bernilai sebagai kreativitas alternatif, suatu barang yang dihasilkan melalui keterampilan tangan" suatu usaha yang dilakukan secara terus menerus dengan penuh semangat ketekunan, kecekatan, kegigihan, berdedikasi tinggi dan berdaya maju yang luas dalam melakukan suatu karya". Paparan tersebut dapat di simpulan bahwa kerajinan adalah suatu kegiatan yang dilakukan secara terus menerus yang berkaitan dengan perbuatan tangan atau kegiatan 
tangan yang menghasilkan suatu karya. Berdasarkan pengertian tersebut, kerajinan yang dimaksud dalam penelitian ini adalah kerajinan yang menggunakan dan menghasilkan kerajinan tangan. Keterampilan anyaman tradisional yang diperoleh pengrajin secara otodidak dari orang tuanya serta dorongan kebutuhan pada zaman dahulu.

Keterampilan anyaman pada dasarnya sejak lama sudah berkembang dalam kehidupan masyarakat di kepulauan nusantara, "karya seni kriya anyaman awalnya berupa alat-alat kebutuhan rumah tangga sehari-hari untuk keperluan ibu-ibu rumah tangga dan berupa alat-alat upacara etnik, seperti penutup sajian dalam upacara adat dan sebagainya. Kepandaian dalam menuang imajinasi dalam penggunaan pandan yang tumbuh di tengah tengah perkampungan masyarakat telah dikenal sejak lama oleh masyarakat Indonesia. Mengenai kaitan antara kebutuhan "spiritual dan fungsional". Kerajinan tradisional merupakan salah satu "warisan budaya bangsa yang dibina”, dilestarikan dan dikembangkan. Bahwa kerajinan tradisional cukup potensial untuk dijadikan sumber lapangan pekerjaan karena merupakan proses pembuatan berbagai macam barang dengan mengandalkan tangan dan peralatan sederhana dalam lingkungan kelompok masyarakat itu sendiri.

\section{Methods}

Metode pelaksanaan pengabdian kepada masyarakat ini dilaksanakan dengan metode penelitian berbasis berbasis riset dengan melakukan pengkajian ekonomi masyarakat terlebih dahulu sebelum melaksanakan pengabdian. Metode ini untuk menggerakkan dan perubahan sosial (Hanafi, dkk, 2015: 11). Hasil kajian ataupun penelitian awal dijadikan sebagai dasar untuk melaksanakan kegiatan pengabdian agar pengabdian masyarakat yang dilaksanakan sesuai dengan kebutuhan masyarakat, khususnya dalam peningkatan ekonomi keluarga melalui pelatihan anyaman.

Pengabdian berbasis riset bagi Majelis taklim dan Rabithah wirid yasin ini juga dilengkapi dengan riset aksi dengan kegiatan pendampingan dan ini dianggap sebagai instrumen yang tepat dalam peningkatan kualitas ekonomi kreatif. Alasan dari penggunaan metode pengabdian berbasis riset agar pengabdian yang dilaksanakan tepat sasaran dan sesuai dengan kebutuhan kelompok Majelis ta'lim dan Rabithah wirid yasin khususnya dalam keterampilan anyaman. Kelompok majelis ta'lim dan Rabithah wirid yasin merupakan suatu aset. Perguruan Tinggi memiliki tanggungjawab sosial untuk dapat berperan dalam pembangunan nasional, kususnya pembangunan masyarakat (Nadhir Salahuddin, dkk, 2015: 1). Beberapa pendekatan yang dipakai dalam pengabdian masyarakat ini antara lain:

1. Partisipasi, pendekatan partisipasi hak keterlibatan dalam kegiatan.

2. Pathnership, membangun kemitraan (pathnership building) merupakan salah satu pendekatan yang sangat efektif diterapkan ke dalam program-program kegiatan. Sasaran dari pathnership adalah membangun keterbukaan, akuntabilitas, juga membangun kontrol bersama, yang diharapkan mampu menumbuhkan trust bersama. 
3. Networking (jaringan kerja), Networking sangat bermanfaat untuk membangun semangat visi gerakan bersama. Kerjasama diantara ketua kelompok majelis ta'lim dan rabithah wirid yasin sebagai kekuatankekuatan dalam mencapai tujuan.

4. Process Oriented (Menghargai Proses), pendekatan yang mencurahkan perhatian pada process oriented ditujukan untuk mempersiapkan secara sungguh-sungguh pengabdian yang berbasis penelitian pada potensi yang dimiliki oleh majelis taklim dan rabithah wirid yasin jorong Batu Badinding Menghargai proses merupakan suatu strategi pengabdian yang berbasis penelitian yang sungguh dimulai dari bawah, sekaligus menyiapkan orientasi pondasi yang kokoh bagi untuk selalu berjuang memperbaiki keadaan.

Adapun strategi dan langkah-langkah yang dilakukan dalam kegiatan yang dilakukan dalam program pengabdian berbasis penelitian adalah sebagai berikut:

1. Need Assessment, sebagai langkah awal untuk mengumpulkan dan merumuskan bentuk-bentuk penguatan bagi guru. Need assessment berupa penelitian yang bersifat kualitatif untuk mendapatkan data dan fakta pembelajaran yang ada di lapangan melalui observasi dan wawancara.

2. Merumuskan Strategic Planing, pengabdian berbasis penelitian. Kegiatan dari tahap ini antara lain menganalisa hasil-hasil temuan dari need assisrnent kemudian mendialogkannya dengan berbagai pihak melalui serangkaian diskusi melalui Focus Group Discussion (FGD). Proses di atas merupakan bagian dari proses pelaksanaan partsipatif (Abdullah Faisol, dkk, 2008: 86).

\section{Results}

Hasil kegiatan pengabdian kepada masyarakat yang dilaksanakan di Batu Badinding sebuah perkampungan dan jorong yang dulunya ditemukan dinding-dinding batu untuk pertahanan, maka masyarakat memberinya nama dengan Batu Badinding (kebenarannya belum di buktikan sejarah baru sebatas pendapat masyarakat), yang berarti kampung yang memiliki banyak batu yang dapat digunakan untuk dinding-dinding. Sebagian masyarakat kampung Batu Badinding pergi merantau. Dan sebagian yang lain masih tetap bertahan di kampung. Ada beberapa rumah di tinggal tanpa penghuni. Faktor kondisi alam yang sempit dan berbukit serta sulitnya kehidupan di perladangan menjadi penyebab alasan mereka untuk merantau. Disamping faktor alam di atas faktor kultur budaya juga menjadi penyebab tingginya minat masyarakat untuk merantau.

Majelis Taklim (MT) dan Kelompok Rabithah Wirid Yasin (RAWIYA) perempuan wirid Yasin pada umumnya dan wirid yasin perempuan pada khususnya merupakan asset lokal atau wadah perkumpulan masyarakat lokal yang masih bertahan bagi masyarakat Kabupaten Pasaman pada umumnya. Dalam perkumpulan ini masyarakat akan meluangkan waktu, disamping untuk kegiatan pokok keagamaan berupa wirid pengajian tetapi juga tempat bagi para perempuan pedesaan untuk menimba berbagai pengetahuan dan pengalaman. Kondisi Majelis Taklim dan Rabithah Wirid Yasin 
secara ekonomi masih rendah dan kurang mandiri dan lemah dalam memanfaatkan sumber daya alam yang ada di sekeliling mereka.

Kegiatan pengabdian masyarakat ini dilakukan dengan mengumpulkan anggota Majelis taklim dan Rabithah wirid yasin dalam suatu kegiatan dengan mendatangkan pelatih yang ahli dalam anyaman. Kegiatan ini lakukan berulang-ulang, mulai dari penentuan tanaman yang akan dijadikan bahan baku anyaman, kemudian pemilihan tanaman yang baik untuk anyaman, pengolahan bahan baku, sampai kepada pembuatan anyaman dan bahkan bagaimana cara memasarkannya. Kegiatan ini lakukan berulang-ulang agar pesertabetul betul dapat dapat memahami dan terampil dalam membuat anyaman. Kegiatan ini merupakan bagian dari pengembangan masyarakat pedesaan yang membutuhkan bimbingsn dan dampingan akademisi. Pertimbangan pemerintah untuk pengembangan pembangunan pedesaan karna 2/3 penduduk Indonesia tinggal di pedesaan (Isbandi Rukminto Adi, 2008: 277).

Oleh karena itu pengabdian berbasis penelitian bagi kelompok Majelis Ta'lim (MT) dan Rabithah wirid yasin (RAWIYA) perlu untuk dilanjutkan dengan keterampilan yang mendukung lainnya dengan harapan agar mereka keluar dari keterpakuan dan minim keterampilan serta dapat memanfaat sumber daya yang ada untuk kemandirian ekonomi dengan keterampilan anyaman tradisional yang bernilai ekonomis untuk menambah pendapatan keluarga.

\section{Discussion}

Pelaksanaan pengabdian masyarakat yang dilaksanakan bagi kelompok majelis Ta'lim dan kelompok Rabithah Wirid Yasin berupa peningkatan ekonomi kreatif melalui keterampilan anyaman tradisional setelah melalui proses yang cukup panjang. Proses mendapatkan dana bantuan BOPTN ini dimulai dari pendaftaran untuk mengikuti kompetitif proposal, memasukkan proposal, seleksi proposal pengabdian sampai akhirnya pada pada penentuan proposal yang dinyatakan lulus dan dipercaya untuk melaksanakan pengabdian masyarakat melalui dana BOPTN.. Adapun Daur program itu antara lain: need assesment, planning, action, reflection yang menjadi satu rangkaian yang utuh.

\section{a. Need Assessment (Melakukan Penjajakan).}

Pengabdi masyarakat dari IAIN Bukittinggi melalaui Lembaga Penelitian dan Pengabdian Masyarakat (LP2M) Institut Agama Islam Negeri (IAIN) Bukittinggi telah membuat proposal (rancangan awal) dalam program ini, namun mengingat banyak permasalahan dalam ekonomi dan keterampilan masyarakat di Jorong Batu Badinding sebagai lokasi pengabdian di atas, maka dilakukan kembali kajian terhadap program yang akan dilaksanakan agar sesuai dengan kebutuhan dan keinginan masyarakat dampingan yakninya para ibu-ibu majelis taklim dan kelompok Rabithah Wirid Yasin di Jorong Batu Badinding kabupaten Pasaman, agar mereka berdaya baik berdaya secara ekonomi dan berdaya pula secara keterampilan.

Peneliti dari IAIN Bukittinggi tepat melalui Lembaga Penelitian dan Pengabdian Masyarakat (LP2M) IAIN Bukittinggi pertama mencoba melakukan orientasi ke Jorong Batu Badinding kabupaten 
Pasaman yang merupakan lokasi pengabdian masyarakat berupa upaya meningkatkan ekonomi kreatif masyarakat melalui pengembangan keterampilan anyaman tradisional dengan soaialisasi, memberikan penguatan, serta lokalatih bagi para ibu-ibu majelis Ta'lim dan Rabithah wirid yasin yang menjadi lokasi untuk melaksanakan kegiatan pengabdian masyarakat melalui peningkatan ekonomi kreatif dengan keterampilan anyaman tradisional. Awalnya Jorong Batu Badinding sebagai tempat atau lokasi pengabdian terlihat sepi karena umumnya masyarakatnya, baik bapak - bapak dan ibu-ibunya berada di sekitaran sawah atau perladangan., Masyarakat sedang beraktivitas di persawahan dan peladangan yang ada di sekitaran perkampungan mereka. Perkampungan ini berada di perlintasan utama lintas Sumatera Padang-Medan yang melintasi jorong Batu Badinding dan beberapa kampung-kampung lain lain yang berada agak di dalam seperti kampung Pangai, Kampung Padang Tarok, kampung Sawah balai, Kampung Balai, Kampung Parak samiak yang merupakan kampung-kampung dalam jorong Batu Badinding.

Informasi yang diperoleh dari pihak pemerintahan Nagari (pemerintahan Desa), dan beberapa masyarakat termasuk para tokoh-tokoh masyarakat di sekitaran jorong Batu Badinding diperoleh informasi bahwa masyarakat Bonjol merupakan salah satu perkampungan yang tergolong sepi di siang hari yang disebab masyarakatnya beraktivitas ke sawah atau ke ladang, adapun industri rumahan boleh katakan tidak ada di kampung Batu Badinding. Ketika anak-anak sudah berangkat ke sekolah maka orang tua pun berangkat beraktivitas ke sawah maupun ke ladang. Kegiatan sosial juga agak sepi dari kegiatan sosial kemasyarakatan seperti surau atau mushalla yang ada di jorong ini juga terlihat sepi dari berbagai aktivitas. Menurut beberapa tokoh masyarakat, termasuk dari pihak diperoleh informasi bahwa faktor penyebab sepi lingkungan masyarakat disebabkan pola kehidupan mereka yang banyak beraktivitas di persawahan dan di perladangan menjadi penyebab utama kampung kelihatan sepi dan hal tersebut juga menjadi kendala utama dalam menyelenggarakan berbagai kegiatan yang akan dilaksanakan di perkampungan mereka. Dalam kaitannya dengan kegiatan pengabdian masyarakat ini, menjadi sebuah kendala atau tantangan tersendiri untuk menggali informasi perkembangan ekonomi keluarga. Hal ini juga menjadi tantangan ketika ingin mengumpulkan masyarakat dalam memberikan kesadaran akan pentingnya peningkatan ekonomi keluarga mealui keterampilan tangan yang kreatif untuk menambah penghasilan keluarga.

Berbagai permasalahan yang timbul dari lapangan di atas dan berdasarkan berbagai informasi di masyarakat maka pengabdi masyarakat IAIN Bukittinggi melalui Lembaga Penelitian dan Pengabdian Masyarakat (LP2M) IAIN Bukittinggi lebih menekankan dan memfokuskan pengabdian kepada ibu-ibu majelis taklim dan Rabithah wirid yasin perempuan melalui kegiatan diskusi terlebih dahulu dengan melakukan diskusi dalam bentuk FGD (Focus Group Discussion) untuk mencari akar permasalahan ekonomi untuk menunjang dan menambah penghasilan keluarga bagi ibu-ibu majelis taklim dan Rabithah wirid yasin yang ada di jorong Batu Badinding, tentang apa sebenarnya yang mereka butuhkan dalam pemberdayaan masyarakat IAIN Bukittinggi bagi peningkatan keluarga melalui ekonomi kreatif anyaman tradisional. 
Pengkajian dari observasi dan riset awal serta beberapa penjajakan didapatkan beberapa hal yang menjadi catatan-catatan bagi pengabdi masyarakat dari IAIN Bukittinggi melalui Lembaga Penelitian dan Pengabdian Masyarakat (LP2M) IAIN Bukittinggi bagi salah satu yang mendapatkan dana pengabdian BOPTN tahun 2018 ini antara lain:

a. Masyarakat khususnya para ibu-ibu rumah tangga secara kemampuan potensi untuk maju dan berkembang sudah memiliki modal dasar dengan keinginan dan kemauan untuk hidup lebih layak. Modal kemauan yang mereka miliki ini dapat dijadikan modal bagi pengembangan kehidupan masyarakat di jorong Batu Badinding ini.

b. Secara potensial sosial, para ibu-ibu majelis ta'lim dan rabithah wirid yasin ini telah memiliki indikator potensi sosial tersebut hal ini dibuktikan dengan kemauan mereka untuk berkumpul bersama dalam satu wadah peningkatan ekonomi keluarga melalaui anyaman tradisional. Potensi sosial ini merupakan modal dasar juga untuk pengembangan ekonomi keluarga. Bagaimanapun potensi sosial menjadi modal bagi seseorang untuk maju dan berkembang.

Kemampun ini juga terlihat dari kemampuan para ibu-ibu majelis taklim dan rabithah wirid yasin untuk untuk berinteraksi dan berkomunikasi dengan peserta masyarakat di sekitar mereka maupun dengan masyarakat komunitas lainnya. Potensi Sosial, yang dimiliki para ibu ibu majelis taklim dan Rabithah wirid yasin tercermin dari kemampuan para ibu-ibu untuk berkomunikasi dan bergaul secara efektif dengan masyarakatnya dan masyarakat sekitar.

\section{Planing (Perencanaan)}

Diskusi, wawancara dan diskusi dari beberapa kegiatan yang dilakukan pada ibu-ibu majelis taklim dan rabithah wirid yasin serta berbincang-bincang ringan dan santai dengan para siswa serta diskusi pula dengan perangkat pemerintahan nagari (pemerintahan desa), dan ditambah dengan diskusi ringan dengan kawan-kawan di kampus sesama pengabdi masyarakat di IAIN Bukittinggi khususnya di LP2M IAIN Bukittinggi, diperoleh pula gambaran tentang segala potensi dan permasalahan yang terjadi di jorong Batu Badinding khususnya lagi dalam hal ekonomi kreatif, maka pengabdian masyarakat dari IAIN Bukittinggi melalui LP2M IAIN Bukittinggi membuat suatu perencanaan yang nantinya sebagai acuan dalam melaksanakan program kegiatan. Adapun rangkuman dari perencanaan yang disusun bersama antara pengabdi masyarakat dengan ibu-ibu majelis taklim dan Rabithah wirid yasin jorong Batu Badinding adalah sebagai berikut:

a Rasionalisasi perencanaan kegiatan pengabdian masyarakat pada peningkatan ekonomi kreatif melalui anyaman tradisional di jorong Batu Badinding adalah sebagai berikut:

1). Rasionalisasi perencanaan kegiatan dapat digunakan sebagai kontrol dalam kegiatan pengabdian masyarakat yang dilakukan pada ibu-ibu majelis talim dan Rabithah wirid yasin di jorong batu Badinding. 
2). Rasionalisasi perencanaan kegiatan untuk dapat menentukan pembagian kerja ketika pengabdian masyarakat, baik pengabdi masyarakat, pendamping lapangan serta pembantu lapangan dari anggota masyarakat itu sendiri

3). Rasionalisasi perencanaan kegiatan untuk dapat dapat dijadikan pedoman dalam melakukan kegiatan pengabdian masyarakat. Dengan adanya rasionalisasi perencanaan maka kegiatan pengabdian sebagai pedomannya.

b. Aspek-Aspek Perencanaan.

Adapun aspek-aspek perencanaan meliputi:

1). Bentuk kegiatan, adapun aspek perencanaan dari aspek bentuk kegiatan berupa kegiatan pengabdian yang memberdayakan masyarakat.

2). Materi kegiatan, adapun materi kegiatan adalah materi yang berhubungan dengan ekonomi kreatif dan berbagai manfaatnya serta keterampilan anyaman tradisional dan berbagai prospeknya.

3). Waktu kegiatan, berupa waktu-waktu yang disepakati dengan masyarakat, agar kegiatan pokok mereka tidak tertinggal dan mereka tidak merasa terganggu dengan kehadiran pengabdi masyarakat, malahan sebaliknya mereka merasa terbantu dengan adanya kegiatan pengabdian masyarakat. Hal ini pemilihan waktu yang tepat sangat menentukan bagi keberhasilan pelaksanaan pengabdian. Apabila waktunya di saat mereka mesti ke ladang atau sawah yang kondisinya tidak bisa di tinggal kan maka mereka tentunya akan memilih sawah atau ladang yang akan mereka datangi.

4). Bentuk evaluasi kegiatan, bentuk evaluasi, adalah dari penilaian terhadap kegiatan yang dilaksanakan, apakah berdaya guna dari kegiatan pengabdian tersebut atau tidak.

c. Waktu kegiatan

Waktu kegiatan pengabdian masyarakat peningkatan ekonomi kreatif melalui anyaman tradisional dilaksanakan sebanyak 6 kali kegiatan. Sedangkan yang menjadi dasar dilakukan perencanaan adalah sebagai berikut:

d. Dasar dilakukan perencanaan.

Adapun yang menjadi dasar dilakukan perencanaan adalah:

1) Berdasarkan hasil diskusi dengan ketua kelompok majelis taklim dan Rabithah wirid yasin perempuan jorong Batu Badinding.

a. Berdasarkan hasil diskusi dengan para anggota majelis ta'lim dan wirid yasin

b. Berdasarkan perbincangan ringan dengan perangkat nagari (perangkat desa) di Nagari Limo Koto tempat pemerintahan jorong Batu Badinding berlokasi. Karena jorong Batu Badinding secara administrasi berada di nagari Limo Koto.

c. Berdasarkan hasil pengamatan ketika observasi mengenai modal kemauan dan modal sosial ibu-ibu majelis taklim dan Rabithah wirid yasin jorong Batu Badinding.

d. Berdasarkan rumusan hasil diskusi baik antara pengabdi masyarakat dengan pemerintahan nagari (pemerintahan desa), diskusi dengan ibu-ibu majleis taklim dan wirid yasin tentang ekonomi kreatif melalui anyaman radisional. 
e. Berdasarkan masukan dari teman sejawat kalangan akademisi dari IAIN Bukittinggi. e. Sosialisasi perencanaan

Pelaksana program pengabdian masyarakat berupa pendampingan oleh pengabdi masyarakat dari IAIN Bukittinggi melalui (LP2M IAIN Bukittinggi) adalah pengabdi masyarakat dengan mitra dampingan sebagai berikut:

1) Ketua majeis ta'lim dan Rabithah Wirid Yasin

2) Anggota majelis ta'lim dan Rabithah wirid yasin

3) Perangkat pemerintah nagari (pemerintah desa setempat)

4) Tokoh masyarakat setempat.

\section{Action}

Pelaksanaan kegiatan pengabdian masyarakat berupa peningkatan ekonomi kreatif melalui anyaman tradisional bagi ibu-ibu majelis ta'lim dan Rabithah Wirid Yasin di jorong Batu Badinding diantaranya adalah dalam bentuk action. Action dilakukan sesuai dengan rencana yang telah dibuat sebelumnya dengan tujuan agar memudahkan dalam pelaksanaannya. Namun ada juga action dilakukan dengan tidak menurut rencana jika di lapangan diperlukan suatu action yang akan membantu sesuai dengan kondisi di lapangan. Hal ini dilakukan dengan pertimbangan fenomena di lapangan dapat saja menambah atau merubah program asalkan tidak menyimpang dari tujuan pokok yaitu peningkatan ekonomi kreatif melalui keterampilan anyaman tradisional bagi ibu-ibu majelis ta'lim dan Rabithah wirid yasin di jorong Batu Badinding kabupaten Pasaman dengan keterampilan anyaman tradisional.

\section{Refleksi}

Pengabdian masyarakat yang dilakukan bertujuan adanya perubahan yang terjadi dalam masyarakat. Refleksi dalam pengabdian masyarakat maksudnya adalah gambaran perubahan yang terjadi sebagai dampak program pembinaan yang dilakukan bagi peningkatan ekonomi kreatif melalui anyaman tradisional bagi Majelis Ta'lim dan Rabithah Wirid Yasin Jorong Batu Badinding kabupaten Pasaman.

\section{B. Pelaksanaan Program.}

1. FGD dan Sosialisasi Pengenalan ekonomi Kreatif Melalui Anyaman Tradisional

Pelaksanaan Kegiatan Sosialisasi berupa workshop pengabdian masyarakat ini berupa kegiatan pengenalan atau mensosialisasikan mengenai ekonomi kreatif yang dapat menambah penghasilan dan pendapatan ekonomi keluarga bagi ibu-ibu majelis ta'lim dan rabithah wirid yasin di jorong Batu Badinding. Sosialisasi dan workshop ekonomi kreatif melalui anyaman tradisional bagi majleis ta;lim dan rabithah wirid yasin dilaksanakan pada tanggal 27-Agustus 2018 yang bertempat di jorong Batu Badinding. Kegiatan sosialisasi ini dengan menghadirkan narasumber yang kompeten di bidang ekonomi kreatif dan desain anyaman tradisional. Sosialisasi dan workshop ekonomi kreatif melalui anyaman tradisional ini dipandang penting untuk dilakukan karena mengingat para ibu-ibu 
majelis ta'lim dan rabithah wirid yasin merupakan ibu-ibu yang rajin dan ulet dalam bekerja dan berusaha. Namun kesempatan untuk mengembangkan kreatifitas bagi ibu-ibu majelis ta'lim dan rabithah wirid yasin ini sangat terbatas. Padahal mereka adalah orang-orang yang pekerja keras, gigih dan bersemangat untuk bekerja. Sayangnya saja mereka bekerja ke ladang dan sawah dan kurang mnegmbangkan diri untuk mencari usaha sampingan untuk memenuhi kebutuhan keluarga yang semakin hari semakin sulit.

Kegiatan sosialisasi berupa workshop peningkatan ekonomi kreatif bagi ibu-ibu yang tergabung dalam majeis ta'lim dan rabithah wirid yasin sangat dibutuhkan dan diperlukan dalam rangka mengembangkan ide-ide dan kreatifitas para ibu-ibu majelis ta'lim dan rabithah wirid yasin untuk menjadi ibu-ibu yang penuh kreatifitas dalam mencari tambahan ekonomi keluarga melalui keterampilan anyaman tradisional. Sebagaimana telah diungkapkan di atas, bahwa peran seorang ibu rumah tangga sangat dalam kelangsungan ekonomi keluarga. Ibu-ibu yang tergabung dalam majelis ta'lim dan rabithah wirid yasin memiliki yang yang penting dalam rumah tangga: peran ibu-ibu dalam peningkatan ekonomi keluarga meliputi banyak hal seperti sebagai perancangan, pendesainan, menghasilkan produk serta yang tidak kalah pentingnya adalah pemasarannya. Bagaimanapun barang produksi yang banyak tanpa diimbangi dengan pemasaran yang lancar justru akan dapat merugikan bagi pencetus ide atau perancangan desain motif keterampilan tangan berupa anyaman tradisional.

\section{FGD dan workshop Penguatan Ekonomi Kreatif Melalui Anyaman Tradisional.}

Focus Group Discussion (FGD) dan workshop penguatan Ekonomi Kreatif melalui anyaman tradisional bagi ibu-ibu majelis ta'lim dan rabithah wirid yasin dilaksanakan pada tanggal 28-8-2018. Kegiatan ini dilaksanakan dengan mendatangkan narasumber yang kompeten dibidangnya dengan harapan dapat memberikan pemahaman yang mendalam kepada peserta berupa FGD dan workshop mengenai ekonomi kreatif melalui anyaman tradisional.

Penguatan terhadap kegiatan sosialisasi dan pengenalan ekonomi kreatif melalui anyaman tradisional bagi ibu-ibu majelis ta'lim dan rabithah wirid yasin bertujuan agar pengetahuan, pemahaman dan pengalaman setelah kegiatan FGD dan Workshop peningkatan ekonomi kreatif bagi ibu-ibu majelis ta'lim dan Rabithah wirid yasin di jorong Batu Badinding dilaksanakan agar ibu-ibu majelis ta'lim dan rabithah wirid yasin dapat menerapkannya ilmu yang diperoleh dari ahlinya (Dr. Nasrul Kamal, M.Sn), sehingga motif dan desain anyaman yang dihasil memiliki nilai jual dan mampu bersaing di tengah maraknya dalam kehidupan sehingga motif-motif anyaman tradisional terlihat lebih menarik. Dengan latihan-latihan yang diberikan kepada ibu-ibu anggota majelis ta'lim dan wirid yasin lebih kuat dalam memahami anyaman tradisional sebagai penambah dan peningkatan anyaman tradisional menjadi lebih kuat dan mendalam.

Kegiatan pengabdian masyarakat berupa peningkatan ekonomi keluarga melalui anyaman tradisional, secara keilmuan bahwa untuk mencapai sebuah tujuan maka FGD dan Workshop atau kegiatan yang dilakukan haruslah berpraktik secara langsung. Praktek ini diharapkan dapat dicapai 
oleh peserta workshop hal ini didasarkan pada sistem pembelajaran bahwa tujuan merupakan komponen yang utama. Segala Aktivitas yang dilakukan baik itu pembelajaran atau pelatihan, mestilah diupayakan untuk mencapai tujuan yang telah ditentukan agar kegiatan yang dilaksanakan lebih mendalam dan lebih kuat dalam pemahaman.

2. Workshop Lokalatih Peningkatan Ekonomi Kreatif Melalui Anyaman Tradisional

Kegiatan Workshop Lokalatih peningkatan ekonomi kreatif melalui keterampilan anyaman tradisional dilaksanakan bagi ibu-ibu majelis ta'lim dan wirid yasin jorong Batu Badinding pada tanggal 29-9-2018 bertempat di jorong Batu Badinding. Kegiatan workshop lokalatih peningkatan ekonomi kreatif melalui anyaman tradisional bagi ibu-ibu majelis taklim dan rabithah wirid yasin bertujuan agar kegiatan sosialisasi dan penguatan yang dilaksanakan sebelumnya lebih dipahami oleh ibu-ibu anggota majelis ta'lim dan rabithah wirid yasin jorong Batu Badinding dengan adanya kegiatan lokalatih berupa latihan bagi pembelajaran desain dan motif anyaman tradisional yang dipelajari sebelumnya.

Lokalatih ini dilakukan bagi ibu-ibu majelis ta'lim dan rabithah wirid yasin dengan pemikiran bahwa ibu-ibu majelis ta'lim dan rabithah wirid yasin sebagai ibu rumah tangga juga memiliki memiliki tanggung jawab yang tinggi untuk meningkatkan ekonomi keluarganya. Ibu-ibu anggota majelis taklim dan rabithah wirid yasin merupakan orang yang ikut mempunyai wewenang serta mempunyai tanggung jawab untuk memenuhi kebutuhan keluarga disamping kewajiban suaminya. Perbedaan latar belakang ekonomi keluarga dari anggota majelis ta'lim dan rabithah wirid yasin yang tidak sama dengan tingkat perbedaan penghasilan dan pendapatan yang berbeda. Adanya perbedaan latar belakang ekonomi keluarga ibu-ibu majelis ta'lim dan rabithah wirid yasin bisa mempengaruhi aktivitas ibu-ibu majelis tersebut dalam menjalankan kehidupan rumah tangganya.

Oleh karena, kegiatan workshop lokalatih peningkatan ekonomi keluarga melalui keterampilan anyaman tradisional bagi ibu-ibui majelis ta'lim dan rabithah wirid yasin sebagai sarana bagi ibu-ibu majelis ta'lim dan rabithah wirid yasin untuk memperkuat pemahaman mereka mengenai ekonomi kreatif dan memperkaya keterampilan mereka mengenai desain motif anyaman tradisional yang menarik dan menyenangkan dalam pembelajaran.

3. Penguatan Data di Lapangan untuk Memperkaya Temuan Pengabdian.

Penguatan data di lapangan sebagai bagian dari memperkaya temuan di lapangan dilakukan untuk menggali bagaimana respon masyarakat terhadap kegiatan pengabdian yang sudah dilakukan seperti kegiatan FGD dan sosialisasi peningkatan ekonomi kreatif melalui anyaman tradisional, FGD penguatan ekonomi kreatif melalui anyaman tradisional serta FGD dan lokalatih peningkatan ekonomi kreatif melalui anyaman tradisional. Beberapa kegiatan FGD dan kegiatan pendampingannya sesuai dengan temanya sebagai penguat data.

Kegiatan riset pengabdian juga dilakukan pengamatan langsung kehidupan sosial ekonomi keluarga para ibu-ibu majelis ta'lim dan rabithah wirid yasin sebagai bagian dari kegiatan pengabdian berbasis riset dalam pengertian bahwa dilakukan dulu kegiatan penelitian dan sebagai basisnya dan 
dengan hasil penelitian awal juga sebagai pegangan dan tempat berpijak dalam melakukan kegiatan pengabdian ditengah-tengah masyarakat.

Kerajinan anyaman tradisional sudah menyebar di berbagai pelosok Tanah Air, satu di antaranya adalah produk kerajinan anyaman tradisional dari pandan bagi kebutuhan ibu-ibu rumah tangga yang dilakukan secara turun-temurun, tetap dibutuhkan guna memenuhi fungsi praktis di kalangan masyarakat luas. Walaupun produk kerajinan masa lampau memiliki kegunaan praktis nilai estetis, simbolis dan spiritualnya luluh bahkan terkadang berada pada fungsi fisiknya. Selanjutnya kerajinan anyaman tradisional sebagai kebutuhan sehari-hari tentang bahan, teknik, bentuk, dan motif pengrajin memerlukan pengetahuannya untuk perkembangan seni anyaman tradisional yang selalu berkembang perlu untuk dilakukan pembaharuan-pembaharuan agar sesuai dengan selera pasar.

Pelaksanaan kegiatan pengabdian berbasis riset oleh pengabdi masyarakat IAIN Bukittinggi melalui LP2M IAIN Bukittinggi mengenai "Peningkatan ekonomi kreatif melalui anyaman tradisional bagi ibu-ibu majelis ta'lim dan rabithah wirid yasin di jorong Batu Badinding dimulai dari kegiatan observasi awal tentang permasalahan untuk pembuatan proposal kemudian dilanjutkan dengan kegiatan riset pendahuluan sebelum kegiatan pengabdian berupa observasi pendalaman, wawancara baik dengan ketua majelis ta'lim dan rabithah wirid yasin, bahkan dengan tokoh masyarakat serta mengamati langsung kehidupan sosial ekonomi masyarakat, maka dapat ditarik satu benang merahnya bahwa sosialisasi dan penguatan serta lokalatih yang tergabung dalam kegiatan pengabdian masyarakat dapat disimpulkan kegiatan pengabdian tersebut dapat meningkat keterampilan para ibuibu majelis taklim dan rabithah wirid yasin.

Hal ini dapat dilihat dari observasi dalam latihan ketika FGD dan workshop peningkatan ekonomi kreatif melalui anyaman tradisional ibu-ibu majelis taklim dan rabithah wirid yasin dapat bekerjasama dalam pelatihan, ibu-ibu majelis ta'lim juga dapat saling menghargai sesama ibu-ibu dalam workshop, membimbing kawan-kawannya dalam bagi yang masih kurang atau lambat dalam memahami motif anyaman tradisional. Secara teori bahwa teknik kerajinan anyaman tradisional dengan cara handmade/buatan tangan, meskipun anyaman tradisional menempati posisi yang lebih rendah dibandingkan dengan kriya lain seperti pembuatan tas kulit atau sendal dan lain-lainnya. namun anyaman tradisional Jorong Batu Badinding merupakan hasil buatan tangan. Semua proses membuat perhiasan dari awal hingga finishing menggunakan tangan (handmade).

\section{Bentuk dan Motif Kerajinan Anyaman Tradisional.}

Kerajinan anyaman tradisional berbentuk benda pelengkap dalam keperluan kehidupan yang lazim digunakan oleh manusia. Bentuk merupakan "apa saja yang dapat dilihat oleh mata, baik itu benda, titik, garis, maupun bidang, yang dapat diukur besarnya, dapat dilihat warnanya dan dapat dirasakan teksturnya" Sedangkan wujud mengungkapkan bahwa "wujud atau form sebagai bentuk, susunan bagian-bagian, aspek visual, dan wujud suatu hasil seni tidak lain adalah bentuknya, susunan bagian-bagiannya, tugasnya, aspeknya yang terlihat" (Read, 1974:16). Bentuk berarti ada wujudnya. 
Demikian pula apabila terdapat dua atau lebih bagian-bagian yang bergabung menjadi satu membentuk suatu susunan terjadilah wujud. Wujud tidak menyangkut soal-soal keteraturan, simetri, ataupun segala macam proporsi tertentu yang lain. Dalam hal ini pemahaman bentuk merupakan bagian dari yang berwujud berupa kerajinan anyaman tradisional yang memiliki volume, panjang dan lebar, di samping bentuk-bentuk motifnya yang beraneka ragam seperti bentuk simetris, yang berbentuk gambaran tentang makna-makna kehidupan.

Menurut Suryanto (2004:39) bentuk merupakan "gambaran umum sesuai atau formasi yang tertutup atau jalur yang tertutup. Banyak cara melukiskan bentuk pada permukaan dua dimensional". Bentuk pada umumnya digunakan untuk menyatakan suatu wujud atau rupa (form),semua yang dapat dilihat baik itu berupa titik, garis maupun dapat disebut dengan benda.

Berdasarkan pendapat di atas, dapat disimpulkan bahwa bentuk adalah penampilan dari fungsi-fungsi yang bekerja atau yang dimiliki oleh benda yang diciptakan. Bentuk memiliki unsurunsur yang tergabung dalam satu kesatuan organisasi. Unsur-unsur tersebut adalah warna, titik, garis, tekstur dan sebagainya.

Sedangkan motif adalah daya pendorong atau tenaga, daya pendorong atau tenaga pendorong yang mendorong manusia untuk bertindak. motif meliputi "segala bentuk ciptaan Tuhan (binatang, tumbuh-tumbuhan, manusia, gunung, air, awan, batu-batuan) demikian pula daya kreasi atau kayal manusia dapat menghasilkan suatu bentuk motif". Motif biasanya digunakan untuk memperindah atau untuk menunjukkan ciri khas dari suatu daerah atau tradisi. Dalam sebuah karya pengrajin tentu telah menimbang aturan-aturan dalam terciptanya produk tersebut, diantaranya adalah komposisi untuk mendapatkan hasil yang baik tentu komposisi suatu karya tidak boleh hilang.

Kegiatan pelatihan anyaman dan pendampinangan bagi anggota Majelis ta'lim dan Rabithah wirid yasin, sebagai bentuk kepedulian dari akademisi bagi masyarakat dengan harapan, adanya partisipasi masyarakat dalam pembangunan, berupa kesukarelaan dari masyarakat dalam suatu pembangunan ( Isbandi Rukminto Adi, 2008, 106).

\section{Conclusion}

Peningkatan ekonomi kreatif melalui anyaman tradisional merupakan salah satu usaha dalam peningkatan kreatifitas dan produktifitas keluarga khususnya bagi ibu-ibu rumah tangga. Banyak waktu luang yang terbuang dengan sia-sia dapat berubah menjadi waktu yang produktif dan bermanfaat dalam kehidupan rumah tangga khususnya dalam menambah penghasilan keluarga.

Menjawab persoalan di atas maka pengabdian masyarakat berbasis riset mengenai peningkatan ekonomi kreatif melalui anyaman tradisional sebagai sarana dan wadah bagi penyadaran terhadap masyarakat khususnya ibu-ibu rumah tangga yang tergolong dalam kelompok majelis ta'lim dan 
rabithah wirid yasin untuk menjadi masyarakat yang hanya sebagai konsumen menuju kepada produsen.

Kegiatan pengabdian masyarakat berupa pelatihan dan pendampingan masyarakat dalam keterampilan anyaman telah membuka mata anggota majelis ta'lim dan rabithah wirid yasin dalam memanfaat tumbuh-tumbuhan yang ada di sekeliling mereka yang dapat dijadikan untuk anyaman. Anggota majelis ta'lim dan rabithah wirid yasin diharapkan dalam kegiatan pengabdian masyarakat ini, dapat memiliki keterampilan dalam membuat anyaman yang bernilai seni sehingga dapat untuk dijadikan oleh-oleh atau cenderamata bagi wisatawan yang datang berkunjung ke kecamatan mereka yakni kecamatan Bonjol yang menjadi salah satu destinasi wisata sejarah di kabupaten Pasaman. Keterampilan mereka dalam membuat anyaman sekaligus sebagai modal dalam meningkatkan pendapatan ekonomi keluarga melalui keterampilan anyaman.

\section{Bibliography}

A Bandi .2009. Pembelajaran Seni Budaya dan Keterampilan, Jakarta: Direktorat Jenderal Pendidikan Islam Departemen Agama RI

Adi, Isbandi, Rukminto, (2008). Intervensi Komunitas: Pengembangan Masyarakat Sebagai Upaya

Pemberdayaan Masyarakat. Jakarta: Rajawali Press

Bastomi, Suwaji .2003. Apresiasi Kesenian Tradisional, IKIP Semarang Press.

Burke, Peter .2000. Sejarah dan Teori Sosial. Bandung: Remaja Rosda Karya Offset.

Djelantik, A.A.M, 1999, Estetika Sebuah Pengantar. Bandung: MSPI.

Faisal, Abdullah. 2008. Metode dan Tekhnik KKN Transformatif. Surakarta: LP2M IAIN Press

Gustami, SP., 1990. "Konsep-konsep Produk Kriya Tadisional Indonesia, Analisis, Desain Melalui Pendekatan Sosial Budaya”, Makalah Seminar Kriya ISI Yogyakarta

Hanafi, Muhammad, dkk. Community Based Research. 2015. Surabaya: UINSA Press,

Hurairah, Abu. 2008. Pengorganisasian dan Pengembangan Masyarakat. Bandung: Humaniora.

Koentjaraningrat. 1989. Seni Tradisional Masyarakat, Jakarta: Sinar Harapan.

Salahuddin, Nadhir, dkk. 2015. Panduan KKN ABCD. Surabaya : UINSA Press 